\title{
STUDI KELAYAKAN PEMBUKAAN PROGRAM STUDI BAHASA PRANCIS, FAKULTAS ILMU BUDAYA, UNIVERSITAS UDAYANA
}

\author{
Nyoman Rauh Artana, Putu Weddha Savitri \\ Fakultas Ilmu Budaya Universitas Udayana \\ rauhartana@gmail.com,weddha_savitri@unud.ac.id
}

\begin{abstract}
Abstrak
Penelitian ini dimotivasi oleh fonemena kenaikan jumlah wisatawan asing asal Prancis yang berkunjung ke Bali, akan tetapi, hal tersebut tidak diikuti dengan kesiapan sumber daya manusia yang layak untuk melayani kebutuhan wisatawan tersebut. Fakultas Ilmu Budaya, Universitas Udayana berencana untuk membuka Program Studi Sastra Prancis sebagai bentuk tanggung jawab institusi terhadap masyarakat sebagai penyedia sumberdaya manusia yang terdidik dan terlatih.

Data dikumpulkan melalui kuisioner yang disebar ke sekolah menengah atas di Bali yang memiliki jurusan bahasa. Data-data yang terkumpul kemudian diklasifikasikan berdasarkan pertanyaan yang telah disiapkan untuk mengetahui persepsi dan keminatan murid sekolah menengah umum terhadap rencana dibukanya program studi bahasa Prancis. Data yang telah terkumpul menunjukkan responden memiliki minat yang tinggi terhadap bahasa Prancis, dan memiliki respon positif terhadap rencana pembukaan Program Studi Bahasa Prancis, di Fakultas Ilmu Budaya, UNUD.
\end{abstract}

Kata kunci : Studi Kelayakan, PS. Bahasa Prancis

\section{PENDAHULUAN}

Bali merupakan provinsi yang pendapatan utamanya bersumber pada sektor pariwisata. Infrastruktur yang memadai telah dibangun setiap tahunnya untuk mendukung pengembangan industry pariwisata lebih maksimal. Tidak hanya fasilitas trasportasi, tetapi juga berbagai pilihan akomodasi yang dapat menyesuaikan dengan kebutuhan wisatawan pun semakin gencar dipromosikan.

Kunjungan wisatawan ke Bali selain sebagai lahan untuk para pencari kerja di bidang jasa, kebutuhan stake holder akan pekerja yang terdidik dan terlatih juga dilihat sebagai peluang bisnis untuk menyediakan lembaga pendidikan terkait. Selain sekolah tinggi kepariwisataan negeri, di Bali menjamur sekolah singkat untuk menjadi tenaga terlatih sebagai penjual jasa di industry pariwisata. Waktu yang singkat tentu saja tidak cukup waktu untuk melatih kemampuan berbahasa siswa yang berkesolah di akademi tersebut. Mereka pada akhirnya terjun menjadi pelaku pariwisata yang tidak siap. Kurangnya kemampuan berbahasa dan pemahaman terhadap budaya asal wisatawan secara umum tentu dapat memberi kesan negatif. Hal ini tentu mengkhawatirkan mengingat sumber mata pencaharian sebagian besar penduduk Bali bertumpu di sektor ini.

Wawasan luas pelaku pariwisata mengenai budaya wisatawan menjadi kebutuhan penting untuk menjaga keberlangsungan prestasi Bali sebagai daerah kunjungan wisata terbaik kedua setelah pulau Galapagos pada tahun 2015 versi 
majalah Travel dan Leisure ${ }^{1}$. Di era globalisasi saat ini, tidak cukup hanya berbekal bahasa Inggris untuk melayani turis yang datang dari berbagai belahan dunia. Meskipun sebagian besar wisatawan mancanegara dapat berbahasa Inggris, akan tetapi, beberapa negara lainnya dikarenakan berbagai alasan mengalami kesulitan berkomunikasi menggunakan bahasa Inggris, seperti negara Prancis dan Jepang.

Wisatawan Prancis yang datang ke Bali semakin bertambah setiap tahunnya. Tahun 2017 dikatakan naik hingga $23.76 \%$, sebanyak 19.153 orang $^{2}$. Sayangnya hal tersebut tidak diikuti dengan peningkatan sumberdaya manusia yang cakap berbahasa Prancis. Meninjau hal tersebut, Fakultas Ilmu Budaya, Universitas Udayana, berencana membuka program studi Bahasa Prancis untuk mencetak lulusan mahir berbahasa Prancis sesuai kebutuhan para stakeholder. Pembukaan program studi baru ini dilakukan dengan mempertimbangkan persepsi murid SMA terhadap rencana dibukanya program studi tersebut sebagai calon mahasiswa yang prospektif.

\section{TINJAUAN PUSTAKA}

Beberapa tinjauan pustaka dan teori digunakan untuk membantu proses analisis dalam penelitian ini. Pengamatan mengenai Persepsi Murid SMA terhadap Pembukaan Program Studi Bahasa Prancis, Fakultas Ilmu Budaya, Universitas Udayana sangat perlu dilakukan sebagai upaya menguji besarnya minat para murid SMA untuk melanjutkan studi ke program studi ini. Penelitian mengenai studi kelayakan telah dilakukan oleh beberapa universitas dengan maksud dan tujuan yang sama, yang sangat berguna digunakan sebagai referensi dalam penelitian ini. Berikut adalah penelitian yang dimaksud.

Setemen, dkk. (2009) mempublikasikan studi lapangan mereka mengenai kelayakan pembukaan program Diploma III UNDIKSHA. Penelitian mereka lakukan ke sekolah menengah atas sebagai

1 http://travel.kompas.com/read/2016/01/04/173936827/Bali.Pulau. Terbaik.Kedua.di.Dunia(diakses 10 Juli 2017)

2 http://www.beritasatu.com/destinasi/386357-kunjungan-turis-pranciske-bali-naik-2736-persen.html(diakses 10 Juli 2017) calon mahasiswa yang potensial dan staf Universitas Pendidikan Ganesha sebagai prasyarat kesiapan dibukanya program diploma yang dimaksud dari unsur internal institusi.

Studi lapangan juga dilakukan ke stakeholder sebagai pengguna lulusan. Studi lapangan tersebut membuktikan bahwa Undiksha sudah cukup memadai untuk menopang pembukaan program Diploma III Teknologi Informasi. Hal tersebut ditentukan karena luasnya jangkauan pekerjaan yang membutuhkan lulusan diploma III Teknologi Informasi serta kesiapan faktor internal maupun eksternal dari sarana maupun prasarana dari Undiksha

\section{PEMBAHASAN}

\subsection{Daerah Pengambilan Data}

Data penelitian ini diambil dari beberapa SMAN di tujuh kabupaten dan satu kotamadya di Bali. Kuisioner yang disebarkan sebanyak 25 lembar per sekolahnya, kepada murid kelas xii. Hal ini didasari bahwa, murid yang akan lulus merupakan sasaran input pembukaan program studi Bahasa Prancis. Tidak semua sekolah di seluruh Bali, dan juga tidak semua kabupaten kota yang dijadikan sebagai daerah pengambilan data. Hal tersebut karena waktu dan kondisi bencana alam yang terjadi di daerah Karangasem yang membuat peneliti mempertimbangkan untuk tidak menyebarkan kuisioner di daerah terdampak erupsi Gunung Agung.

Pertanyaan-pertanyaan dalam kuisioner berkaitan dengan minat murid SMA terhadap Negara Prancis, Bahasa Prancis, potensi pariwisata wisatawan Prancis, maupun minat murid SMA untuk melanjutkan studi mereka memperdalam bahasa Prancis sebagai salah satu bahasa PBB ke perguruan tinggi, khususnya Universitas Udayana. Kemudian, dari 329 data yang diberikan 15 data adalah data invalid, yaitu kuisioner yang diberikan ada yang dijawab tidak sesuai dengan instruksi ataupun tidak dikembalikan. Berikut adalah sekolah yang dijadikan daerah pengambilan data, yaitu :

1. Kotamadya Denpasar : SMAN 1 Denpasar 
SMAN 3 Denpasar

SMAN 4 Denpasar

SMKN 4 Denpasar

2. Kabupaten Gianyar :

SMAN 1 Ubud

3. Kabupaten Buleleng :

SMAN 1 Singaraja

SMAN 2 Singaraja

SMAN 3 Singaraja

SMAN 4 Singaraja

4. Kabupaten Badung :

SMAN 1 Kuta Selatan

SMKN 1 Kuta Selatan

5. Kabupaten Klungkung :

SMAN 1 Semarapura
SMAN 2 Semarapura

SMAP Saraswati Klungkung

6. Kabupaten Tabanan :

SMAN 1 Tabanan

SMKN Biwi Tabanan

\subsection{Hasil Keseluruhan Kuisioner Studi Kelayakan Bahasa}

Hasil keseluruhan kuisioner tersebut menunjukkan sebagian besar responden menyatakan adanya urgensi untuk dibukanya program studi bahasa Prancis, mengingat potensi ekonomisnya di masa depan. Hal ini memberikan dukungan secara langsung bagi Fakultas Ilmu Budaya, Universitas Udayana untuk segera membuka program studi

Hasil Keseluruhan Kuisioner Studi Kelayakan Bahasa Prancis

\begin{tabular}{|c|c|c|c|c|c|c|}
\hline No. & $\begin{array}{l}\text { Pertanyaan mengenai studi kelayakan pembukaan Program } \\
\text { Studi Bahasa Prancis di Fakultas Ilmu Budaya, Universitas } \\
\text { Udayana }\end{array}$ & $\begin{array}{c}\text { Sangat } \\
\text { Penting }\end{array}$ & Penting & $\begin{array}{c}\text { Biasa } \\
\text { Saja }\end{array}$ & $\begin{array}{c}\text { Tidak } \\
\text { Penting }\end{array}$ & $\begin{array}{c}\text { Sangat } \\
\text { Tidak } \\
\text { Penting } \\
\end{array}$ \\
\hline 1 & $\begin{array}{l}\text { Apakah menurut anda penting untuk menguasai bahasa } \\
\text { asing lain selain bahasa Inggris di era globalisasi saat ini? }\end{array}$ & 133 & 141 & 35 & 4 & 1 \\
\hline 2 & $\begin{array}{l}\text { Apakah menurut anda bahasa Prancis, sebagai salah satu } \\
\text { bahasa resmi PBB, memiliki kedudukan yang penting di } \\
\text { dunia international? }\end{array}$ & 17 & 137 & 147 & 13 & o \\
\hline 3 & $\begin{array}{l}\text { Apakah menurut anda bahasa Prancis memiliki peran yang } \\
\text { penting di berbagai bidang pekerjaan di daerah anda? }\end{array}$ & 12 & 64 & 181 & 45 & 12 \\
\hline 4 & $\begin{array}{l}\text { Apakah menurut anda penting di Bali, sebagai daerah } \\
\text { wisata, mneyediakan tenaga kerja cakap berbahasa Prancis } \\
\text { yang memadai? }\end{array}$ & 49 & 157 & 83 & 15 & 10 \\
\hline 5 & $\begin{array}{l}\text { Apakah menurut anda penting cakap berbahasa Prancis } \\
\text { agar siap menghadapi globalisasi? }\end{array}$ & 33 & 129 & 127 & 22 & 3 \\
\hline 6 & $\begin{array}{l}\text { Apakah menurut anda penting untuk mempelajari bahasa } \\
\text { Prancis di perguruan tinggi? }\end{array}$ & 30 & 107 & 145 & 29 & 3 \\
\hline 7 & $\begin{array}{l}\text { Apakah menurut anda penting perguruan tinggi } \\
\text { menyediakan program studi bahasa Prancis bagi calon } \\
\text { mahasiswa yang berminat? }\end{array}$ & 68 & 153 & 69 & 20 & 4 \\
\hline 8 & $\begin{array}{l}\text { Apakah menurut anda penting dibukanya program studi } \\
\text { bahasa Prancis di Bali sebagai daerah kunjungan wisata? }\end{array}$ & 46 & 148 & 97 & 19 & 4 \\
\hline 9 & $\begin{array}{l}\text { Apakah menurut anda penting bagi Fakultas Ilmu Budaya } \\
\text { UNUD untuk menyediakan tenaga kerja terdidik dan } \\
\text { terlatih berbahasa Prancis untuk memenuhi kebutuhan } \\
\text { pasar, terutama yang berkaitan dengan bahasa Prancis? }\end{array}$ & 65 & 152 & 80 & 11 & 6 \\
\hline 10 & $\begin{array}{l}\text { Apakah menurut anda penting bagi Fakultas Ilmu Budaya } \\
\text { untuk membuka Program Studi Bahasa Prancis? }\end{array}$ & 60 & 139 & 91 & 15 & 9 \\
\hline & Total Keseluruhan Responden & \multicolumn{5}{|c|}{329} \\
\hline & Valid & \multicolumn{5}{|c|}{314} \\
\hline & Invalid & \multicolumn{5}{|c|}{15} \\
\hline
\end{tabular}


Bahasa Prancis sebagai langkah nyata kontribusi universitas kepada masyarakat untuk mencetak tenaga kerja terdidik khususnya yang mampu berbahasa Prancis di dunia kerja.

\section{SIMPULAN}

Penelitian ini merupakan studi kelayakan terhadap rencana dibukanya program studi baru di Fakultas Ilmu Budaya, Universitas Udayana, yaitu ProgramStudi Bahasa Prancis. Rencanapembukaan program studi Bahasa Prancis merupakan bentuk tanggung jawab nyata Universitas Udayana untuk menciptakan sumber daya manusia terdidik yang berkualitas terutama dalam bidang bahasa Prancis di dunia kerja.

Responden studi kelayakan ini adalah murid SMU kelas XII di tujuh kabupaten kota di Bali, yang merupakan input bagi program studi ini di masa depan. Sebagian besar responden menyatakan penting untuk menguasai bahasa Prancis sebagai bahasa PBB selain bahasa asing lainnya, yaitu bahasa Inggris, di masa globalisasi saat ini. Selain itu, sebagian besar responden juga berpendapat secara positif bahwa penting bagi Fakultas Ilmu Budaya, Universitas Udayana untuk membuka program studi bahasa Prancis segera.

\section{UCAPAN TERIMA KASIH}

Penulis menyampaikan terima kasih kepada Rektor Universitas Udayana, Ketua Lembaga Penelitian dan Pengabdian Kepada Masyarakat (LPPM) Universitas Udayana, dan Dekan Fakultas Ilmu Budaya, dan pendanaan PNPB sehingga penelitian ini dapat terselesaikan. Semoga penelitian ini dapat memberi sumbangan ilmiah khususnya bagi bidang pengajaran bahasa asing. Semoga penelitian ini dapat memberikan sumbangan ilmiah, terutama dalam bidang pengembangan kebahasaaan.

\section{DAFTAR PUSTAKA}

Firmin, M. 2008.Data Collection. In L.M Given (eds). The Sage Encyclopedia of Qualitative Reasearch Methods. California: Sage

Setemen, Komang. dkk. 2009. StudiKelayakanPembukaan Program Diploma III TeknologiInformasi UNDIKSHA Singaraja. JPTK, UNDIKSHA, VOL. 6, NO.1., Januari 2009: 1-16. ISSN 0216-3241.

Tim, 2003.Undang-Undang Republik Indonesia Nomor 20 Tahun 2003 tentang Sistem Pendidikan Nasional, Biro Hukum dan Organisasi Depdiknas, Jakarta.

Tim, 2004. Rencana Strategis Fakultas PendidikanTeknologi Kejuruan, IKIP Negeri Singaraja.

Zainal, Hasibuan, 2007. Kontribusi Dunia Pendidikan dalam Bidang Teknologi Informasi untuk Dunia Usaha/Industri. Makalah disampaikan pada Seminar Jurusan Manajemen Informatika tanggal 7 Mei 2007. 